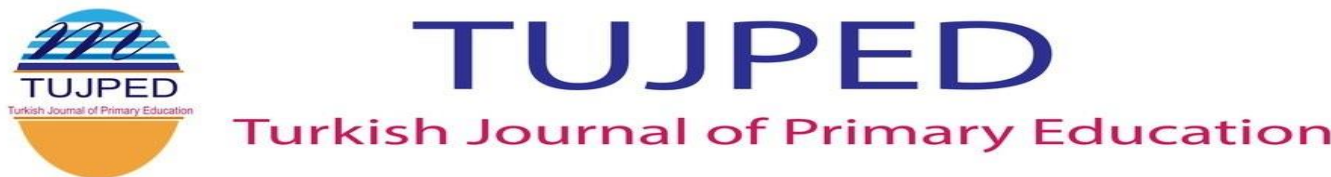

Turkish Journal of Primary Education, 2021, 6 (1), 89-108

\title{
Fen Bilimleri Öğretmenlerinin Derslerinde Okul Bahçelerini Kullanma Durumlarının İncelenmesi**
}

\author{
Gamze GÜLEN ${ }^{1}$ \& Aykut Emre BOZDOĞAN ${ }^{2}$ \\ ${ }^{1}$ Tokat Gaziosmanpaşa Üniversitesi, Türkiye \\ ${ }^{2}$ Tokat Gaziosmanpaşa Üniversitesi, Türkiye
}

\begin{abstract}
$\ddot{O}_{z e t}$
Bu araştırmada, fen bilimleri ögretmenlerinin derslerinde okul bahçelerini kullanma durumlarının çeşitli değişkenler açısından bütünsel olarak değerlendirilmesi amaçlanmıştır. Araştırmanın problemini ve alt problemlerini daha detayl inceleyebilmek için hem nitel hem de nicel verilerden yararlanilan karma yöntem (mixed method) kullanılmıştır. Araştırma Tokat ilindeki ortaokullarda görev yapan 53 erkek ve 60 kadın olmak üzere toplam 113 fen bilimleri ögretmeni ile gerçekleştirilmiştir. Öğretmenlerin okul bahçesi kullanım durumlarının belirlenmesi amacıyla araştırmacı tarafından geliştirilen ve iki bölümden oluşan Okul Bahçesi Kullanım Durumu Anket Formu uygulanmıştır. Araştırmanın alt problemlerine yönelik verilerin istatistiksel çözümleri için betimsel istatistik yöntemlerinden frekans ve yüzde analizi kullanılmıştır. Açık uçlu sorular ise içerik analizine göre analiz edilmiştir. Araştırma sonuçları öğretmenlerin neredeyse yarısının derslerinde okul bahçelerini kullandı̆̆ını, kullanan ögretmenlerin ise çoğunluğunun okul bahçesini düzensiz aralıklarla ve dersin anlatımı amacıyla kullandiğını göstermektedir. Ayrıca ortaokul 5., 6., 7. ve 8. sinıf seviyeleri öğrenme alanları açısından incelendiğinde, ögretmenlerin okul bahçelerini en fazla "Fiziksel Olaylar" öğrenme alanında kullandı̆̆ görülmektedir.
\end{abstract}

Anahtar kelimeler: Okul bahçesi, fen bilimleri dersi, fen bilimleri ögretmeni, fen eğitimi

\section{The Evaluation of the Use of School Gardens by Science Teachers in Their Lectures}

\begin{abstract}
The purpose of this study is the evaluation of use of school gardens by science teachers during their lectures in regard to different variables. In this study, a mixed method combining both quantitative and qualitative data is used to examine the research topic in more detail. This study is conducted with a total amount of 113 middleschool science teachers (53 male and 60 female) working in elementary schools in the city of Tokat, Turkey. In order to evaluate the status of use of school gardens by the teachers, a questionnaire consisting of two parts (the questionnaire for the status of use of school gardens) developed by the researcher is applied to the teachers. Descriptive statistical methods of frequency and percentage were used for statistical solutions of the data. Openended questions are analyzed according to content analysis. The results of the research show that almost half of the teachers use the school gardens in their lectures, and the majority of the teachers who do use the school garden at irregular intervals and as a replacement of lectures for the purpose of lecturing. In addition, in terms of learning categories for middle-school $5^{\text {th }}, 6^{\text {th }}, 7^{\text {th }}$, and $8^{\text {th }}$ grades, it is seen that teachers mostly use the school gardens in the "Physical Events" learning category.
\end{abstract}

Keywords: School garden, science course, science teacher, science education

\footnotetext{
*Sorumlu yazar e-mail: gulengamzeagirman@gmail.com Orcid No: 0000-0002-5061-0945

** Bu çalışma 658169 kodlu "Fen bilimleri öğretmenlerinin derslerinde okul bahçelerini kullanma durumlarının incelenmesi: Tokat ili örneği” adlı yüksek lisans tezinden üretilmiştir.
}

DOI: $10.52797 /$ tujped.925015 


\section{GİRİ̧}

Günümüzde eğitim ve öğretim faaliyetleri artık okul içi veya sınıf ile sınırlı kalmayıp faydalı olacağı düşünülen her türlü okul dışı öğrenme ortamlarında gerçekleştirilecek bir sürece dönüşmüştür (Saraç, 2017). Öğrencilerin eğitim yaşantılarının sınıf içerisine hapsedilmesi ve gerçek hayattan uzaklaştırılması zaten eleştirilen bir durumdur (Özer, 2007). Çünkü sadece okul içinde gerçekleştirilmeye çalışılan bir eğitim-öğretim süreci, öğrencilerin öğrenmeyi günlük hayatla bağlantısı olmayan, doğallıktan uzak, kısaca suni faaliyetler olarak görmelerine sebep olabilir (Kılıç, 2001). Okul dışı öğrenme kavramı; okul sınırlarının dışında bulunan çeşitli yaşam alanlarından sanal ortamlara kadar birçok alanı kapsamaktadır (Eshach, 2007). Dolayısıyla okul dışında yapılan faaliyetlerin doğada ve yaşanılan çevrede yapılan, eğitim amaçlı aktiviteleri içeren öğrenme süreçlerini kapsadığı ifade edilebilmektedir (Tatar \& Bağrıyanık, 2012).

Öğrencilerin okul dışındaki ortamlarda bu faaliyetleri yürüteceği derslerin başında ise fen dersleri gelmektedir. Çünkü fen eğitiminin hedefleri arasında, öğrencilerin doğal dünyayı anlamaları ve öğrenmeleri, bunun verdiği düşünsel zenginliği ve heyecanı yaşamalarını sağlamak vardır (MEB, 2005). Eliason ve Jenkins'e (2003) göre fen günlük hayatımızın bir parçasıdır ve bu nedenle fen eğitimi çocuklar açısından anlamlı ve günlük yaşamlarıyla ilişkilendirilmiş olarak eğitim programlarına dâhil edilmelidir. Fen öğretiminin ağırlıklı olarak yapıldığı gözlemlenen üç öğrenme ortamı bulunmaktadır. Bunlar: sınıf, laboratuvar ve okul dışı mekânlardır (Orion \& Hofstein, 1994). Sınıf ve laboratuvar ortamları fen dersleri için sınırlı birer öğrenme ortamı olmakta ancak fen öğrenmede okul dişı mekânlar öğrencilere birçok fursatlar sunmaktadır (Carrier, 2009). Bu nedenle günümüzde önem kazanan okul dişı çevreler Milli Eğitim Bakanlı̆̆ı'nın özellikle fen öğretim programlarında yer almakta ve yapılacak olan farklı etkinliklerin imkânlar dâhilinde bu öğrenme ortamları içerisinde yapılması gerektiği vurgulanmaktadır (MEB, 2018). Fen öğretiminin daha faydalı olması için bilim merkezleri, müzeler, hayvanat bahçeleri, botanik bahçeleri, planetaryumlar gibi okul dişı öğrenme ortamlarının kullanılması gün geçtikçe artmakta ve fen eğitimcilerinin dikkatini çekmektedir (Smith, McLaughlin \& Tunnicliffe, 1998).

Okul dışı öğrenme ortamları kapsamında literatürde farklı sınıf düzeylerinde ve farklı okul dışı çevrelerde birçok çalışmaya rastlanmaktadır. Bunlardan akvaryumların (Falk \& Adelman, 2003), müzeler ve bilim merkezlerinin (Aktekin, 2008; Sturm \& Bogner, 2010), hayvanat bahçelerinin (Yavuz, 2012), enerji parkının (Balkan, Kıyıcı \& Atabek Yiğit, 2010; Ertaş, Şen \& Parmaksızoğlu, 2011), botanik bahçelerinin (Wiegand, Kubisch \& Heyne, 2013), sanayi kuruluşlarının (Bozdoğan, Okur \& Kasap, 2015) ve milli parkların (Güler, 2009) çeşitli araştırmalarda kullanıldığı görülmektedir. Bunlara ek olarak okul dışı öğrenme ortamlarına yapılan gezilerin akademik başarı ve tutuma etkisi (Bozdoğan, 2008; Sturm \& Bogner, 2010; Şentürk \& Özdemir, 2014; Yavuz, 2012), okul dış1 öğrenme ortamlarının; öğrenciye deneyim kazandırması (Bozdoğan \& Yalçın, 2006; Tatar \& Bağrıyanık, 2012), gözlem becerisi ile kalıcı bilgi edinmeyi sağlaması (Balkan Kıyıcı ve Atabek Yiğit, 2010), öğrencinin günlük hayatla ilişki kurmasını kolaylaştırması (Ertaş, Şen \& Parmaksızoğlu, 2011; Tortop \& Özek, 2013), öğrencinin bilişsel ve duyuşsal yönde gelişmesini sağlaması (Berberoğlu \& Uygun, 2013; Güler, 2009; Tatar \& Bağrıyanık, 2012) ve çevre bilinci oluşturmasına (Berberoğlu ve Uygun, 2013) ilişkin çalışmalarda bulunmaktadır. Görüldüğü üzere okul dışı eğitim ortamları öğrencilere birçok yönde olumlu kazanımlar sağlamaktadır. Buna rağmen öğretmenlerin çoğunlukla bu ortamları tercih etmedikleri görülmektedir (Carrier, 2009; Tatar ve Bağrıyanık, 2012). Bunun sebebinin de öğretmenlerin yeterli bilgiye (Güler, 2009) ve öz-yeterliğe sahip 
olmaması ve kaygılanması olduğu ortaya konulmuştur (Bozdoğan, 2015). Ayrıca ulaşım sıkıntısı, zaman sıkıntısı, sınıfların kalabalık olması, öğrenci kontrolünün zor olması ve bir takım resmi işlemlerin bulunması bu tür etkinliklerin öğretmenler tarafından tercih edilmesini de güçleştirmektedir (Erten \& Taşç1, 2016; Karademir, 2013). Bu nedenle okul dişı ortamlara yapılan gezilerde karşılaşılan bürokratik işler, ulaşım, maddi yetersizlikler vs. gibi sorunların okul bahçelerinde yapılacak etkinliklerde karşılaşılmaması, bu ortamların alternatif olarak sunulabileceğini göstermektedir.

Okul bahçeleri öğrencilerde olumlu psiko-fiziksel özellikler geliştirmeye ve sağlıklı bir ortamda yeni bilgi edinmeye teşvik etmek açısından büyük önem arz etmektedir (Geušić, 2020). $\mathrm{Bu}$ sebeple okulun inşa edileceği alanın özellikleri, okul binasının yapısal ve fiziksel özellikleri, okul bahçesinin estetik yapısı ve düzenlemeleri gibi etkenlere çok dikkat edilmeli; estetik ve eğitsel açıdan gereken değeri taşımasına önem ve özen gösterilmelidir (Iş11, 1991; Stephen \& Crawley,1994). Yurt dışında yapılmış olan çalışmalarda okul bahçesi kavramının ülkemizden farklı olarak daha ziyade bitki yetiştirilen bir bahçe olarak tasarlandığı görülmektedir (Rye, Selmer, Pennington, Vanhorn, Fox \& Kane, 2012). Bu yeşil temalı bahçeler öğrencilerin ve öğretmenlerin kendini ifade edebilme, yaratıcılık, inovasyon ve yeme alışkanlıklarının olumlu yönde şekillenmesine katkıda bulunmakta, ayrıca öğrenci ve öğretmenlerin günlük hayatta zamanı daha iyi yönetme becerisi elde etmelerine de olanak sağlamaktadır (Thorp \& Townsend, 2001). Ayrıca Amerika Birleşik Devletleri'ni kapsayan bir derleme çalışmasında genel olarak okul bahçelerinin öğrencilerin fen başarısını ve yeme alışkanlıklarını pozitif yönde etkilediği görülmektedir (Blair, 2009). Bunula birlikte yapılan bir çalışmada beslenme programı ve okul bahçesinin birbiriyle örtüşmesi gerektiği ve öğrencilerin kendileri tarafindan okul bahçesinde yetiştirilen sebzelerin beslenme saatinde tüketilmesi sayesinde öğrencilerin beslenme alışkanlığına olumlu katkılarda bulunduğu görülmektedir (Graham, Beall, Lussier, McLaughlin \& Zidenberg-Cherr, 2005; Morgan, Warren, Lubans, Saunders, Quick \& Collins, 2010). Ayrica okul bahçeleri tecrübeyle öğrenme açısından firsat sağlamakta ve öğrenilen bilgilerin ise pekiştirilmesine yardımcı olmaktadır (Skelly \& Bradley, 2000). Robinson \& Zajicek (2005) tarafindan yapılan bir çalışmada bir yıl boyunca "Okul Bahçesi Programı"na dâhil olan öğrencilerin dahil olmayan öğrencilere kıyasla hayat becerinin yüksek oranda geliştiği ifade edilmektedir. Okul bahçesi uygulamaları, öğrencilerin fen bilimleri dersine ilişkin tutumlarını olumlu yönde etkilemekte ve bu sebeple gelişimleri üzerinde de olumlu yönde bir etki gösterdiği de görülmektedir (Ürey \& Çepni, 2014). Okul bahçesinin eğitim sürecindeki etkilerini inceleyen birçok çalışma, öğrencilere çok sayıda fayda sağladığını göstermekte olup bunlardan birinin de deneyimsel öğrenmeyi sağlamasıdır (Başar, 2020; Papadopoulou, Kazana \& Armakolas, 2020). Bahçe temelli öğrenme (Garden Based Learning [GBL]) doğayla iç içe olmayı, yaparak ve yaşayarak öğrenmeyi sağlamakta ve bu sayede öğrencilerin fen dersine yönelik ilgilerini yükseltmektedir (Riggs, 2020).

Literatürde okul bahçelerinin etkili kullanılmasına yönelik çeşitli çalışmalara rastlanmakla birlikte ülkemizde okul bahçelerinin kullanılma durumları noktasında yeterli düzeyde çalışmaya rastlanmamıştır. Bu noktada fen bilimleri öğretmenlerinin okul bahçelerini kullanım durumlarının hangi değişkenler tarafından etkilendiğinin belirlenmesinin önemli olduğu düşünülmektedir. Yapılan bu çalışmayla literatüre bu konuda katkı sağlanacağı söylenebilir. 


\section{Araştırmanın Amacı}

$\mathrm{Bu}$ çalışmanın amacı fen bilimleri öğretmenlerinin derslerinde okul bahçelerini kullanma durumlarının farklı değişkenler açısından incelenmesi olarak belirlenmiştir. Araştırma problemi çerçevesinde aşağıdaki sorulara yanıtlar aranmıştır.

1) Araştırmaya katılan öğretmenlerin derslerinde okul bahçesini kullanma sıklıkları ne düzeydedir?

2) Araştırmaya katılan öğretmenler okul bahçesini en çok hangi ünitede/ünitelerde kullanmaktadirlar?

3) Araştırmaya katılan öğretmenler okul bahçesi kullanım sürecinde ne gibi problemlerle karşılaşmaktadır?

4) Araştırmaya katılan öğretmenlerin okul bahçesini etkili kullanma hakkında meslektaşlarına önerileri nelerdir?

5) Araştırmaya katılan öğretmenlerin derslerinde okul bahçesi kullanmalarının öğrencilere ne tür katkıları olduğuna dair görüşleri nelerdir?

6) Araştırmaya katılan ve okul bahçesini kullanmayan öğretmenlerin okul bahçesini kullanmama nedenleri nelerdir?

\section{YÖNTEM}

\section{Araştırma Modeli}

$\mathrm{Bu}$ çalışmada, araştırmanın problemini daha detaylı inceleyebilmek ve probleme cevaplar aramak adına hem nitel hem de nicel veriler toplanmıştır. Bu yöntem karma yöntem (mixed method) olarak adlandırılır (Tashakkori \& Teddlie, 2003). Ayrıca araştırmada karma yöntem desenlerinden biri olan ve Cresswell (2003) tarafından tasarlanan sıralı açıklayıcı tasarım deseni kullanılmıştır. Karma yöntem nicel ve nitel araştırma arasında bir köprü kurulmasına yardımcı olur (Onwuehbuzie \& Leech, 2004) ve sonuçlar arasında ilişkiyi kuvvetlendirir.

\section{Örneklem}

Araştırmanın ulaşılabilir evrenini Tokat ilindeki ortaokullarda görev yapan 330 fen bilimleri öğretmenleri oluşturmaktadır. Araştırmanın örneklemini ise Tokat ilinde görev yapan fen bilimleri ögretmenleri arasından orantısız tabakalı örneklemle seçilen ve ulaşılması mümkün olan toplam 113 öğretmen oluşturmaktadır. Tabakalı örneklem genelde yaş, cinsiyet, gelir düzeyi gibi kendi içlerinde heterojen ama genel manada homojen dağılan demografik değişkenleri içeren bir örneklem türüdür (Baştürk \& Taştepe, 2013). Araştırmanın örneklemini belirlemek amacı ile Tokat İl Milli Eğitim Müdürlüğü'nden Tokat genelindeki ortaokulların listesi alınmıştır. Ayrıca özel eğitim okullarında görev yapan fen bilimleri öğretmenleri de bu çalışmaya dâhil edilmiştir.

Tablo 1. Örneklemin Demografik Özellikleri

\begin{tabular}{llcc}
\hline Demografik Bilgiler & & f & $\%$ \\
\hline Cinsiyet & Erkek & 53 & 46,9 \\
& Kadın & 60 & 53,1 \\
Mezuniyet durumu & Eğitim Fakültesi & 104 & 92 \\
& Fen Edebiyat Fakültesi & 9 & 8 \\
Hizmet yılı & $1-10$ yıl & 48 & 42,5 \\
& $11-20$ yıl & 48 & 42,5 \\
& 21 yil ve üzeri & 17 & 15 \\
\hline
\end{tabular}


Tablo 1 incelendiğinde araştırmaya katılan 113 fen bilimleri öğretmeninden 53'ünün $(\% 46,9)$ erkek, 60'ının $(\% 53,1)$ ise kadın olduğu görülmektedir. Öğretmenlerden 104'ünün (\%92) Eğitim Fakültesi mezunu, 9'unun $(\% 8,0)$ ise Fen Edebiyat Fakültesi mezunu olduğu belirlenmiştir. Yine öğretmenlerden 48'inin $(\% 42,5)$ 1-10 yıl hizmet yaptığ, 48 'inin $(\% 42,5)$ $10-20$ yıl hizmet yaptığ ve 17 'sinin $(\% 15,0)$ ise 21 yıl ve üzerinde süredir görev yaptığ 1 tespit edilmiştir.

\section{Veri Toplama Araçları}

Araştırmanın verileri araştırmacılar tarafından hazırlanmış olan ve iki bölümden oluşan anket formundan elde edilmiştir. Anket, belirlenen bir konuda belirlenmiş hipotezlere bağlı kalınarak evreni temsil eden bir örneklemi veya evrenin tamamının kaynağını oluşturan kişilere önceden belirlenen birtakım soruların yöneltildiği sistemli bir veri toplama tekniği olarak adlandırılır (Balc1, 2005).

Okul bahçesi kullanım durumu anket formu: Okul bahçesi kullanım durumu anket formu araştırmacılar tarafından bu araştırma için geliştirilmiş orijinal bir formdur. Anket formu geliştirilirken öncelikle literatür taraması yapılmış ve bu doğrultuda taslak anket formu oluşturulmuştur. Anket formunun geliştirilmesinden sonra geçerlik çalışması yapılmıştır. Bir anket formunda en fazla kullanılan geçerlik yöntemi kapsam geçerliğidir. Ankette bulunan soruların içeriği, anketin amacına uygunluğu ve bir bütün halinde incelendiğinde soruların bu bütünlüğü oluşturup oluşturmadığı kapsam geçerliliğini ifade etmektedir. Bir anket formunun kapsam geçerliliğini sağlamanın birtakım yöntemleri bulunmaktadır. Bunlardan birisi konu alanındaki uzmanlara başvurmaktır. Ayrıca anket formu oluşturulurken anketin uygulanacağı bireylere araştırmacı tarafından önceden hazırlanan açık uçlu birtakım soruların yöneltilmesi ve ön deneme yapılması anket formunun kapsam geçerliliğini yükseltir. Anket formuna 2 fen eğitimi uzmanı, 3 fen bilimleri öğretmeni ayrıca imla ve yazım kuralları bakımından 1 Türkçe öğretmenin görüşleri alınarak üzerinde gerekli düzeltmeler yapılmış ve son hali verilmiştir. Yapılan düzenlemelerde kompleks cümleler basitleştirilmiş ve anlam bütünlüğü sağlanmıştır. Anket formu iki bölümden oluşmaktır. Birinci bölüm öğretmenlere ait cinsiyet, kıdem yılı, mezuniyet durumu, okutmakta oldukları sınıf seviyeleri, okul bahçesi kullanıp kullanmama ve okul bahçesini dersin hangi aşamasında kullandıkları gibi 7 adet demografik bilgiden oluşan kapalı uçlu soruları barındırmaktadır. İkinci bölüm ise yine bir adet kapalı uçlu soru ve 4 adet açık uçlu soru olmak üzere toplam 5 adet sorudan oluşmaktadır.

\section{Veri Toplama Süreci}

Araştırma verileri 2018-2019 Eğitim-öğretim yılı bahar dönemi içerisinde toplanmıştır. Veriler Tokat ili ve ilçelerinde çeşitli okullarda görev yapan fen bilimleri öğretmenlerinden bireysel olarak araştırmacı tarafından toplanmıştır. Bu süreçte araştırma anketi araştırmacı tarafından bireysel olarak öğretmenlere dağıtılmış, anket formları doldurulmadan önce gerekli açıklamalar yapılmış ve 72 saat içinde anketler araştırmacı tarafından tekrar toplanmıştır. Veri toplama çalışmaları 12.03.2019-28.03.2019 tarihleri arasında sürdürülmüştür. Uygulanan anket sayısı 197 olup geri dönüş alınan anket sayısı 113'tür. Değerlendirilen 113 ankette herhangi bir veri kaybına rastlanmamıştır. 


\section{Verilerin Analizi}

Araştırmanın genel amacı çerçevesinde cevapları aranan alt problemlere yönelik veriler anket kullanılarak toplanmış olup verilerin gerekli istatistiksel çözümleri için betimsel istatistik yöntemlerinden frekans ve yüzde kullanılmıştır. Sayısal sonuçlarla ilgili veriler tablolar haline getirilip yorumlanmıştır. Açık uçlu sorular ise içerik analizine göre analiz edilmiştir. İçerik analizi metinlerin düzenlenmesi ve sınıflandırılması, karşılaştırılması ve bu metinlerden teorik birtakım sonuçlar çıkarılmasından oluşan bir araştırma tekniğidir (Cohen, Manion \& Morrison, 2007). Ayrıca içerik analizi, birbirine benzeyen verilerin belirli temalar ve kavramlar çerçevesinde bir araya getirilerek daha anlaşılır bir biçime dönüştürülmesi olanağ sağladığından tercih edilmiştir (Fraenkel \& Wallen, 2000; Yıldırım \& Şimşek, 2005). Araştırma verileri herkesin anlayabileceği şekilde çeşitli ana başlıklar ve alt başlıklar altında toplanmış ve görüşlerin tekrarlama sıklığına göre gruplandırılmıştır. Ayrıca örnek öğretmen görüşleri de eklenerek bulgular kısmında okuyuculara sunulmuştur. Öğretmenlere ait görüşler eklenirken öğretmenlerin cinsiyetlerini ve anket numaralarını temsil eden kısaltmalar kullanılmıştır. Erkek öğretmenler için " $E$ " kadın öğretmenler için ise " $K$ ”" kısaltmaları kullanılmış, numaralandırma ise anket numarasina göre "E11”, “E72”, “E3” veya "K20”, “K81”, “K110” şeklinde ifade edilmiştir.

\section{BULGULAR}

Araştırmaya katılan fen bilimleri öğretmenlerinin okul bahçesini kullanma sıklıkları incelenmiş ve Tablo 2'te verilmiştir.

Tablo 2. Fen bilimleri öğretmenlerin derslerinde okul bahçesini kullanma sıklığının frekans ve yüzde dağılımı

\begin{tabular}{lc}
\hline Okul bahçesi kullanım sıklı̆̆ & $\mathrm{f}$ \\
\hline Düzensiz aralıklarla & 33 \\
Yılda en az bir kez & 12 \\
Ayda en az bir kez & 7 \\
Dönemde en az bir kez & 7 \\
Haftada en az bir kez & 5 \\
Kullanmıyorum & 49 \\
Toplam & 113 \\
\hline
\end{tabular}

Tablo 2 incelendiğinde derslerinde okul bahçesini kullanan 64 öğretmenden 33'ünün okul bahçesini düzensiz aralıklarla kullandığı, 12'sinin yılda en az bir kez kullandığ 1 , 7'sinin ayda en az bir kez kullandığı, 7'sinin dönemde en az bir kez kullandığı ve 5'inin de haftada en az bir kez kullandığı görülmektedir. 49 öğretmen okul bahçelerini derslerinde kullanmadığını ifade etmişstir.

Araştırmaya katılan fen bilimleri öğretmenlerinin okul bahçesini dersin hangi ünitelerinde kullandıkları incelenmiş ve Tablo 3 'te verilmiştir. Tablo 3 incelendiğinde 5. sınıf seviyesindeki öğrencilerin dersine giren 51 öğretmenden 31'inin $(\% 60,78)$ fen bilimleri dersinde okul bahçesini İnsan ve Çevre ünitesinde kullandığı, 28'inin $(\% 54,90)$ Canlılar Dünyası ünitesinde kullandığı, 26'sının $(\% 50,98)$ Kuvvetin Ölçülmesi ve Sürtünme ünitesinde kullandığı, 22'sinin $(\% 43,13)$ Güneş, Dünya ve Ay ünitesinde kullandığı, 18'inin $(\% 35,29)$ Işı̆̆ın Yayılması ünitesinde kullandığı, 4'ünün $(\% 7,84)$ Madde ve Değişim ünitesinde kullandığı, 3'ünün $(\% 5,88)$ ise Devre Elemanları ünitesinde kullandığı görülmektedir. 6. sinıf seviyesindeki öğrencilerin dersine giren 46 öğretmenden 36’sının $(\% 56,25)$ fen bilimleri dersinde okul 
bahçesini Kuvvet ve Hareket ünitesinde kullandığı, 21'inin $(\% 45,65)$ Güneş Sistemi ve Tutulmalar Dünya ve Evren ünitesinde kullandığı, 21'inin $(\% 45,65)$ Ses ve Özellikleri ünitesinde kullandığg1, 10'unun (\%21,73) Madde ve Isı ünitesinde kullandığı, 3'ünün (\%6,52') Vücudumuzdaki Sistemler ünitesinde kullandığı, 3'ünün (\%6.52) Vücudumuzdaki Sistemler ve Sağlığı ünitesinde kullandığı, 1'inin (\%2.17) Elektriğin İletimi ünitesinde kullandığ1 görülmektedir. 6. sınıf öğrenme alanları bakımından ele alındığında öğretmenlerin okul bahçesini en çok "Canlılar ve Yaşam" öğrenme alanı, en az ise "Fiziksel Olaylar" öğrenme alanı konularında işlediği görülmektedir.

Tablo 3. Fen bilimleri öğretmenlerinin okul bahçesini derslerindeki hangi ünitelerde kullandıklarına ilişkin frekans ve yüzde dağılımı

\begin{tabular}{|c|c|c|c|c|}
\hline Sinif & Üniteler & Öğrenme Alanları & $\mathrm{f}$ & $\%$ \\
\hline \multirow{6}{*}{$\begin{array}{l}\text { 㟧 } \\
\text { in }\end{array}$} & 6. ünite (İnsan ve Çevre) & Canlılar ve Yaşam & 31 & 60,78 \\
\hline & 2. ünite (Canlılar Dünyası) & Canlılar ve Yaşam & 28 & 54,90 \\
\hline & 3. ünite (Kuvvetin Ölçülmesi ve Sürtünme) & Fiziksek Olaylar & 26 & 50,98 \\
\hline & 1. ünite (Güneş, Dünya ve Ay) & Dünya ve Evren & 22 & 43,13 \\
\hline & 5. ünite (Işı̆̆ı̆n Yayılması) & Fiziksek Olaylar & 18 & 35,29 \\
\hline & $\begin{array}{l}\text { 4. ünite (Madde ve Değişim) } \\
\text { 7. ünite (Devre Elemanları) }\end{array}$ & $\begin{array}{l}\text { Madde ve Doğası } \\
\text { Fiziksek Olaylar }\end{array}$ & $\begin{array}{l}4 \\
3\end{array}$ & $\begin{array}{l}7,84 \\
5,88\end{array}$ \\
\hline \multirow{7}{*}{$\begin{array}{l}\stackrel{4}{\Xi} \\
\vec{\omega} \\
\stackrel{0}{6}\end{array}$} & 3. ünite (Kuvvet ve Hareket) & Fiziksek Olaylar & 36 & 78,26 \\
\hline & 1. ünite (Güneş Sistemi ve Tutulmalar Dünya ve Evren) & Dünya ve Evren & 21 & 45,65 \\
\hline & 5. ünite (Ses ve Özellikleri) & Fiziksek Olaylar & 21 & 45,65 \\
\hline & 4. ünite (Madde ve Is1) & Madde ve Doğası & 10 & 21,73 \\
\hline & 2. ünite (Vücudumuzdaki Sistemler) & Canlılar ve Yaşam & 3 & 6,52 \\
\hline & 6. ünite (Vücudumuzdaki Sistemler ve Sağlığı) & Canlılar ve Yaşam & 3 & 6.52 \\
\hline & 7. ünite (Elektriğin İletimi) & Fiziksel Olaylar & 1 & 2.17 \\
\hline \multirow{7}{*}{ 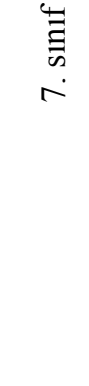 } & 3. ünite (Kuvvet ve Enerji) & Fiziksel Olaylar & 24 & 51,06 \\
\hline & 5. ünite (Işı̆̆ın Madde ile Etkileşimi) & Fiziksek Olaylar & 16 & 34,04 \\
\hline & 1. ünite (Güneş Sistemi ve Ötesi) & Dünya ve Evren & 13 & 27,65 \\
\hline & 7. ünite (Elektrik Devreleri) & Fiziksel Olaylar & 11 & 23,40 \\
\hline & 2. ünite (Hücre ve Bölünmeler) & Canlılar ve Yaşam & 5 & 10,63 \\
\hline & 4. ünite (Saf Madde ve Karışımlar) & Madde ve Doğası & 5 & 10,63 \\
\hline & 7. ünite (Elektrik Devreleri) & Fiziksel Olaylar & 1 & 2.12 \\
\hline \multirow{7}{*}{$\begin{array}{l}\text { 亗 } \\
\infty \\
\infty\end{array}$} & 1. ünite (Mevsimler ve İklim) & Dünya ve Evren & 22 & 51,16 \\
\hline & 6. ünite (Enerji Dönüşümleri ve Çevre Bilimi) & Canlılar ve Yaşam & 21 & 48,83 \\
\hline & 5. ünite (Basit Makineler) & Fiziksek Olaylar & 15 & 34,88 \\
\hline & 3. ünite (Basınç) & Fiziksek Olaylar & 14 & 32,55 \\
\hline & 4. ünite (Madde ve Endüstrisi) & Madde ve Doğası & 4 & 9,39 \\
\hline & 2. ünite (DNA ve Genetik Kod) & Canlılar ve Yaşam & 1 & 2,32 \\
\hline & 7. ünite (Elektrik Yükleri ve Elektrik Enerjisi) & Fiziksek Olaylar & 0 & 0,00 \\
\hline
\end{tabular}


7. sınıf seviyesindeki öğrencilerin dersine giren 47 öğretmenden 24 'ünün $(\% 51,06)$ fen bilimleri dersinde okul bahçesini Kuvvet ve Enerji ünitesinde kullandı̆̆ı, 16'sının $(\% 34,04)$ Işığın Madde ile Etkileşimi ünitesinde kullandığı, 13'ünün $(\% 27,65)$ Güneş Sistemi ve Ötesi ünitesinde kullandığı, 11'inin $(\% 23,40)$ Elektrik Devreleri ünitesinde kullandığı, 5'inin $(\% 10,63)$ Hücre ve Bölünmeler ünitesinde kullandığı, 5'inin $(\% 10,63)$ Saf Madde ve Karışımlar ünitesinde kullandığı, 1'inin (\%2.12) 'sinin ise Elektrik Devreleri ünitesinde kullandığı görülmektedir. 8. sınıf seviyesindeki öğrencilerin dersine giren 43 öğretmenden 22 'sinin $(\% 51,16)$ fen bilimleri dersinde okul bahçesini Mevsimler ve İklim ünitesinde kullandığı, 21 'inin (\%48,83) Enerji Dönüşümleri ve Çevre Bilimi ünitesinde kullandığı, 15 'inin $(\% 34,88)$ Basit Makineler ünitesinde kullandığ1, 14'ünün $(\% 32,55)$ Basınç ünitesinde kullandığ 1 , 4'ünün $(\% 9,39)$ Madde ve Endüstrisi ünitesinde kullandığı, 1'inin $(\% 2,32)$ DNA ve Genetik Kod ünitesinde kullandığı görülmektedir. Elektrik Yükleri ve Elektrik Enerjisi ünitesinde ise hiçbir öğretmenin okul bahçesini kullanmadığı görülmektedir.

Araştırmaya katılan fen bilimleri öğretmenlerinin okul bahçesi kullanım sürecinde ne gibi problemlerle karşılaştı̆̆ incelenmiş ve Tablo 4'te verilmiştir.

Tablo 4. Derslerinde okul bahçesini kullanan fen bilimleri öğretmenlerinin süreçte karşılaştıkları problemlere ilişkin frekans dağılımı

\begin{tabular}{lll}
\hline Tema & Kod & f \\
\hline Problemle karşılaşan & & 45 \\
& Sinıf Yönetimi Yetersizliği & 24 \\
& Bahçenin Fiziki Durumunun Yetersizliği & 15 \\
& Öğrencilerdeki Dikkat Dağınıklığı & 12 \\
& Mevsimsel Etmenler & 7 \\
& Güvenlik Problemleri & 4 \\
& Açık Alanda Duyma ve Not Alma Zorluğu & 3 \\
& Araç -Gereç Yetersizliği & 2 \\
\hline Problemle karşılaşmayan & Okul İdaresinden Kaynaklanan Problemler & 1 \\
\hline
\end{tabular}

Tablo 4 incelendiğinde derslerinde okul bahçesini kullanan 64 öğretmenin 45'inin okul bahçesini kullanırken en az bir problemle karşılaştı̆̆ 1 , 19'unun ise herhangi bir problemle karşılaşmadığ 1 görülmektedir. Bu kapsamda en az bir problemle karşılaştığını ifade eden 45 öğretmenin 24'ünün sınıf yönetimine ilişkin sorunlar yaşadığı görülmüştür. Bu kapsamda bir öğretmen "Çocukları bazen bir arada tutmak zor oluyor. (K4)" derken bir diğer öğretmen ise "Bahçede öğrencilerin düzenini sağlamak zorlaşıyor. (E19)" şeklinde görüş bildirmiştir. Yine öğretmenlerden 15'i bahçenin fiziki yetersizliğinden kaynaklanan problemler yaşadığını dile getirmiştir. Bu kapsamda öğretmenlerden birisi "Oturulacak yer sıkıntısı olabiliyor. (E76)" derken bir diğeri de "Bahçe alanının yeterli olmamasıyla ilgili bir sorun yaşıyoruz. (K46)" şeklinde görüş belirtmiştir. Öğretmenlerden 12'si öğrencilerdeki dikkat dağınıklığından kaynaklanan problemler yaşadığını dile getirmiştir. Bu kapsamda öğretmenlerden birisi "Bahçedeki kargaşadan dolayı çocukların dikkatini etkinliklere vermesi zor oluyor. (K56)" derken bir diğeri de "Evet bazen derse ilgisi olmayan ögrenciler gruptan kopabiliyor. (K66)" şeklinde görüş belirtmiştir. Öğretmenlerden 7'si mevsimsel etmenlerden kaynaklanan problemler yaşadığını dile getirmiştir. Bu kapsamda öğretmenlerden birisi "Güneş ışı̆̆ı gereken durumlarda birden hava kapanabiliyor, yağışlı oluyor. (E75)" derken bir diğeri de "Soğuk hava şartlart yüzünden bahçede ders yapmakta zorlanıyorum. (K14)" şeklinde görüş belirtmiştir. 
Öğretmenlerden 4'ü güvenlikten kaynaklanan problemler yaşadığını dile getirmiştir. Bu kapsamda öğretmenlerden birisi "Olası tehlikelere karşı ögrenciler savunmasız oluyor. (E11)" derken bir diğeri de "Sürat konusunda koşma yaparken bazen düşüp yaralanabiliyorlar. (K32)" ş̧eklinde görüş belirtmiştir. Öğretmenlerden 3'ü ise açık alanda duyma ve not alma zorluğundan kaynaklanan problemler yaşadığını dile getirmiştir. Bu kapsamda öğretmenlerden birisi "Konuşulanların anlaşılması, duyulması zorlaşıyor. (E19)" derken bir diğeri de "Öğrencilerin geniş alanda duyması zorlaşıyor. (K20)" şeklinde görüş belirtmiştir. Yine öğretmenlerden 2'si araç-gereç yetersizliğinden kaynaklanan problemler yaşadığını dile getirmiştir. $\mathrm{Bu}$ kapsamda öğretmenlerden birisi "Araç-gereç yetersizliği bahçede ders işlememizi zorlaştırlyor. (E67)” derken bir diğeri de "Bazen yeterli araç gereç olmayabiliyor. (E83)" şeklinde görüş belirtmiştir. Yine öğretmenlerden 1'i okul idaresinden kaynaklanan problemler yaşadığını dile getirmiştir. Bu kapsamda öğretmen "Okul idaresi derslerin dışarda işlenmesinden rahatsız oluyor. Gerekçe ise; okul disiplini bozulur, herkes böyle yapmak ister, suistimal edilir. (K98)" ş̧eklinde görüş belirtmiştir.

Araştırmaya katılan fen bilimleri öğretmenlerinin okul bahçesini etkili kullanma hakkında meslektaşlarına verdikleri öneriler incelenmiş ve Tablo 5 'te verilmiştir.

Tablo 5. Fen bilimleri öğretmenlerinin derslerinde okul bahçesini etkili kullanma tavsiyelerine ilişkin frekans dağılımı

\begin{tabular}{|c|c|c|c|}
\hline Tema & Kod & Açıklama & f \\
\hline \multirow[t]{11}{*}{ Tavsiyesi Olan } & & & 32 \\
\hline & Planlama & $\begin{array}{l}\text { Bahçede etkinlik yapmadan önce mutlaka etkinliği } \\
\text { planlamalısınız. }\end{array}$ & 9 \\
\hline & & Grubun dikkatini konuya toplayacak etkinlikler seçmelisiniz. & 5 \\
\hline & & $\begin{array}{l}\text { Etkinliklerin bahçeye ve konuya uygun olasına dikkat } \\
\text { etmelisiniz. }\end{array}$ & 5 \\
\hline & & $\begin{array}{l}\text { Etkinlik yönergesini bahçeye çıkmadan önce öğrencilere } \\
\text { dağıtmalı ve açıklamalısınız. }\end{array}$ & 4 \\
\hline & Destek & $\begin{array}{l}\text { Zaman sıkıntısı yaşamamak için zaman planlaması yapmalısınız. } \\
\text { Okul yönetiminden destek alarak, okul bahçesini fen bilimleri }\end{array}$ & 1 \\
\hline & & dersi için verimli hale getirebilirsiniz. & 8 \\
\hline & & Kalabalık sınıflarda yardımcı öğrenciler görevlendirebilirsiniz. & 3 \\
\hline & Güvenlik & Olası kazalar için gerekli güvenlik önlemlerini almalısınız. & 3 \\
\hline & Uygulama & Bazı konu ve üniteler için bahçede çizimler ve şekiller & \\
\hline & & kullanabilirsiniz. & 2 \\
\hline Tavsiyesi Olmayan & & & 32 \\
\hline
\end{tabular}

Tablo 5 incelendiğinde okul bahçesini daha etkili kullanmak adına tavsiyede bulunan 32 öğretmenden 24'ü bahçenin daha verimli kullanılabilmesi için planlama yapılması gerektiği yönünde görüş bildirmiştir. Bu kapsamda 24 öğretmenden 9'u "Bahçede etkinlik yapmadan önce mutlaka etkinliği planlamalısınız" yönünde görüş bildirmiştir. $\mathrm{Bu}$ kapsamda öğretmenlerden biri "Yapılan etkinlik önceden mutlaka planlanmalıdır. (E8)" ifadesini kullanırken bir diğer öğretmen ise "Ders iyi planlanmalıdır. (K20)" ifadesini kullanmıștır. Yine öğretmenlerden 5'i “Grubun dikkatini konuya toplayacak etkinlikler seçmelisiniz." yönünde görüş bildirmiştir. Bu kapsamda öğretmenlerden biri "Öğrencilerin dikkatinin dağılmaması konusunda önlemler almalısınız, dikkat çekici etkinlikler seçmelisiniz. (K13)" ifadesini kullanırken bir diğer öğretmen ise "Grubun dikkatinin dă̆llmasını engelleyici etkinlikler seçmelisiniz. (E7)" ifadesini kullanmıştır. Öğretmenlerden 5'i "Etkinliklerin bahçeye ve konuya uygun olasına dikkat etmelisiniz." yönünde görüş bildirmiştir. Bu kapsamda öğretmenlerden biri “Özellikle güzel havalarda dersi bahçede işlemek Fen bilimleri dersinin 
amacına daha uygun oluyor. (E76)" ifadesini kullanırken bir diğer öğretmen ise "Halat çekme, ışık ve çevre konularındaki etkinliklerde bahçeyi kullanabilirler. (K59)” ifadesini kullanmıştır. Yine öğretmenlerden 4'ü "Etkinlik yönergesini bahçeye çıkmadan önce öğrencilere dağıtmalı ve açıklamalısınız." yönünde görüş bildirmiştir. Bu kapsamda öğretmenlerden biri "Bahçeye çıkmadan önce araç ve gereçlerin kullanım talimatları hatırlatılmalıdır. (E67)" ifadesini kullanırken bir diğer öğretmen ise "Öğrencilere etkinlik yönergesi önceden hazırlanıp verilmeli ve ögrenciler görevlendirilmelidir. (K20)” ifadesini kullanmıştır. Öğretmenlerden 1'i ise "Zaman sıkıntısı yaşamamak için zaman planlaması yapmalısınız." yönünde görüş bildirmiştir. $\mathrm{Bu}$ kapsamda öğretmen "Ö̈̆rencileri dışarı çıkardı̆̆ımızda öğrenci kontrolü çok zor olacağından zamanlamayı iyi yapmamız lazım. (E20)” ifadesini kullanmıştır.

32 öğretmenden 11'i bahçenin daha verimli kullanılabilmesi için destek alınması gerektiği yönünde bir ifade kullanmıştır. Bu 11 öğretmenden 8'i “'Okul yönetiminden destek alarak, okul bahçesini fen bilgisi dersi için verimli hale getirebilirsiniz." yönünde görüş bildirmiştir. $\mathrm{Bu}$ kapsamda öğretmenlerden biri "Okul bahçelerinde ögrencilerin bitki yetiştirebileceği alan, basit makinelerden oluşan bir alan ve oyun oynayabilecekleri ayr bir alanı okul yönetiminden isteyebilirsiniz. (K29)" ifadesini kullanırken bir diğer öğretmen ise "Bahçe oluşturulurken boş bir alan birakılmall, bu alan taşla döşenmemeli ayrıca bu alan beden ĕgitimi derslerinin yapıldığı alandan uzakta olmalıdır. Okul yönetimi ile bu konu hakkında iş birliği yapabilirsiniz. (K97)" ifadesini kullanmıştır. Yine öğretmenlerden 3'ü "Kalabalık sınıflarda yardımcı öğrenciler görevlendirebilirsiniz." yönünde görüş bildirmiştir. Bu kapsamda öğretmenlerden biri “Kalabalık sınıflarda yardımcı ögrenciler seçilmeli ve görevlendirilmeli. (K20)” ifadesini kullanırken bir diğer öğretmen ise "Gruplar küçük olmalı ve yardımcı öğrenciler seçilmelidir. (K97)" ifadesini kullanmıştır.

32 öğretmenden 3'ü bahçenin daha verimli kullanılabilmesi için güvenlik önlemi alınması gerektiği yönünde bir ifade kullanmış ve "Olası kazalar için gerekli güvenlik önlemlerini almalısınız." yönünde görüş bildirmiştir. Bu kapsamda öğretmenlerden biri "Çevre şartlarına dikkat edilmelidir. (E101)" ifadesini kullanırken bir diğer öğretmen ise "İş güvenliğine dikkat edilmeli ve ögrencilerin başında durulmadır. (E28)" ifadesini kullanmıştır. Yine 32 öğretmenden 2'si bahçenin daha verimli kullanılabilmesi için uygulama yöntemi adına tavsiyelerde bulunmuştur. Yine öğretmenlerden 2'si de "Bazı konu ve üniteler için, bahçede çizimler ve şekiller kullanabilirsiniz." yönünde görüş bildirmiştir. $\mathrm{Bu}$ kapsamda öğretmenlerden biri "Bahçede kullanılan çizimler çocuklar üzerinde etkili oluyor. (E34)" ifadesini kullanırken bir diğer öğretmen ise "Okul bahçesini dersime uygun olacak şekilde tasarlayabilirim. Örneğin; periyodik cetvel çizimi, elementlerle seksek oyunu gibi. (K10)" ifadesini kullanmıştır. Araştırmaya katılan 64 öğretmenden 32'si ise meslektaşlarına herhangi bir tavsiyede bulunmamıştır.

Tablo 6. Fen bilimleri öğretmenlerinin derslerinde okul bahçesini kullanmasının öğrencilere sağladığı katkılara ilişkin görüşlerinin frekans dağılımı

\begin{tabular}{lllll}
\hline Tema & Kod & Açılkama & & $\mathrm{f}$ \\
\hline Öğrenme Alanı & Psikomotor & $\begin{array}{l}\text { Yapma, hayata geçirme, zihin ve kas becerilerini birlikte } \\
\text { kullanma }\end{array}$ & 39 \\
& Bilişsel & $\begin{array}{l}\text { Açıllama, inceleme, hatırlama, gösterme, deneme, } \\
\text { ilişkilendirme }\end{array}$ & 37 \\
& $\begin{array}{l}\text { Değer verme, saygılı olma, motivasyon, iş birliği, } \\
\text { heyecanlanma }\end{array}$ & 30 \\
\hline
\end{tabular}


Araştırmaya katılan fen bilimleri öğretmenlerine göre okul bahçesinin öğrenciler üzerindeki olumlu etkileri incelenmiş ve Tablo 6'da verilmişstir. Tablo 6 incelendiğinde dersinde okul bahçesini kullanan 64 öğretmenden 39'unun okul bahçesi kullanımının öğrencilerin psikomotor becerilerine katkısı olduğu yönünde görüş bildirmiştir. Bu kapsamda bir öğretmen "Yaparak yaşayarak öğrenme firsatı doğuyor. (K24)" derken bir diğer öğretmen ise "Oyun oynayarak ders işlendiği için daha kalıcı oluyor. (E64)" şeklinde görüş bildirmiştir. Öğretmenlerden 37'sinin öğrencilerin bilişsel becerilerine katkısı olduğu yönünde görüş bildirmiştir. Bu kapsamda bir öğretmen "Kavramada kolayllk să̆llyor. (K69)” derken bir diğer öğretmen ise "Başka disiplinlerle ilişkilendirmeyi sağllyor. (K13)" şeklinde görüş bildirmiştir. 30 öğretmen ise öğrencilerin duyuşsal becerilerine katkısı olduğu yönünde görüş bildirmiştir. Bu kapsamda bir öğretmen "Dersi daha heyecanll takip ediyorlar (K12)" derken bir diğer öğretmen ise "Ĕglenerek öğrenmeyi sağllyor. (K58)" şeklinde görüş bildirmiştir.

Araştırmaya katılan ve derslerinde okul bahçesini kullanmayan fen bilimleri öğretmenlerinin okul bahçesini kullanmama nedenleri incelenmiş ve Tablo 7'de verilmiştir.

Tablo 7. Derslerinde okul bahçesini kullanmayan fen bilimleri öğretmenlerinin okul bahçesi kullanmama sebeplerine yönelik frekans dağılımı

\begin{tabular}{lll}
\hline Tema & Kod & f \\
\hline En az bir problemle karşılaşan & & 49 \\
& Bahçedeki Öğrenci Yoğunluğu & 29 \\
& Bahçenin Fiziki Yetersizliği & 16 \\
& Sinıf Yönetimi Yetersizliği & 11 \\
& Bahçeye İhtiyaç Duymama & 10 \\
& Konu ve Ünitelere Uygunluk & 9 \\
& Zaman Yetersizliği & 9 \\
& Öğrencilerdeki Dikkat Dağınıklığı & 6 \\
& Araç- Gereç Yetersizliği & 6 \\
& Mevsimsel Etmenler & 4 \\
& Okul İdaresinden Kaynaklanan Problemler & 4 \\
& Güvenlik Problemleri & 2 \\
\hline
\end{tabular}

Tablo 7 incelendiğinde okul bahçesi kullanımına engel teşkil eden en az bir problemle karşılaştığını ifade eden 49 öğretmenin 29'unun okul bahçesindeki öğrenci yoğunluğuna ilişkin sorunlar yaşadığı görülmüştür. Bu kapsamda bir öğretmen "Aynı anda çok sayıda sınıfın bahçede olmast. (E5)" derken bir diğer öğretmen ise "Sinıfların kalabalık olması nedeniyle bahçede kaos olacağını düşünüyorum. (K25)" şeklinde görüş bildirmiştir. Yine öğretmenlerden 16'sının bahçenin fiziki yetersizliğine ilişkin sorunlar yaşadığ 1 görülmüştür. Bu kapsamda bir öğretmen "Bahçe çok küçük. (K17)" derken bir diğer öğretmen ise "Okul bahçesi beton. (E65)" şeklinde görüş bildirmiştir. Yine öğretmenlerden 11'inin sınıf yönetimine ilişsin sorunlar yaşadığı görülmüştür. Bu kapsamda bir öğretmen "Sınıf kalabalık ve bahçede oyun, etkinlik kontrolü zor. Kullanmayı isterim ancak kullanamam. (K17)" derken bir diğer öğretmen ise "Öğrenci kontrolünün daha zor olmast. (E30)" şeklinde görüş bildirmiştir. Öğretmenlerden 10'unun bahçeye ihtiyaç duymama/sınıf ve laboratuvarı yeterli görme durumundan kaynaklanan sorunlar yaşadığı görülmüştür. Bu kapsamda bir öğretmen "Aynı etkinlikleri gösteri yoluyla sınıf ortamında yapabiliriz. (E88)" derken bir diğer öğretmen ise "Fen bilimlerinin bütün konularında bahçenin kullanılmasını gerekli görmüyorum. (K61)" şeklinde görüş bildirmiştir.

Öğretmenlerden 9'unun bahçenin konu ve ünitelere uygun olmayışına ilişkin sorunlar yaşadığı görülmüştür. $\mathrm{Bu}$ kapsamda bir öğretmen " $\mathrm{Bu}$ yıl ki 7. sınıf müfredatında bahçe kullanımını gerektirecek bir üniteyi henüz işlememiş olmak. (K79)” derken bir diğer öğretmen ise 
"Girdiğim sınıflarda şu zamana kadar okul bahçesinde ders işleyecek konunun yer almaması. (E16)" şeklinde görüş bildirmiştir. Yine öğretmenlerden 9'unun zamana ilişkin sorunlar yaşadığı görülmüştür. Bu kapsamda bir öğretmen "Zaman sıkıntısı. (E2)" derken bir diğer öğretmen ise "Zaman kaybı olduğunu düşünüyorum. 7. ve 8. sinıf ögrrencileri sinava hazırlaniyor, zamanı tekrar yapmaya ve test çözmeye harcıyorum. 6. sinıflarda ise konular ancak yetişiyor. (K91)" şeklinde görüş bildirmiştir. Öğretmenlerden 6'sının ise öğrencilerdeki dikkat dağınıklığı durumundan kaynaklanan sorunlar yaşadığı görülmüştür. Bu kapsamda bir öğretmen "Öğrencilerin dikkati dă̆llıyor, oyun oynamak istiyorlar. (K63)" derken bir diğer öğretmen ise "Okulumuz ana cadde yanında olduğundan ses fazla miktarda var, ögrencinin dikkatli rahatlıkla dağılabiliyor. (E81)" ş̧eklinde görüş bildirmiştir. Yine öğretmenlerden 6'sının araç-gereç yetersizliğinden kaynaklanan sorunlar yaşadığı görülmüştür. Bu kapsamda bir öğretmen "Deney yapılacak malzemelerin götürülüp getirilmesinde sıkıntı yaşanması. (K40)" derken bir diğer öğretmen ise "Okul bahçesinde derse yönelik ilgi çekici materyaller bulunmamaktadır. (K94)" șeklinde görüş bildirmiştir. Yine öğretmenlerden 4'ünün mevsimsel etmenlerden kaynaklanan sorunlar yaşadığı görülmüsştür. Bu kapsamda bir öğretmen " $K$ lş aylarında soğuk olduğu için kullanmıyorum. (E6)" derken bir diğer öğretmen ise "Hava muhalefeti. (K23)" şeklinde görüş bildirmiş̧tir. Öğretmenlerden 4'ünün okul idaresinden kaynaklanan sorunlar yaşadığ 1 görülmüştür. Bu kapsamda bir öğretmen "Olumsuz bir sonuç oluştuğunda yaptırımların ă̆ır olması. (E55)" derken bir diğer öğretmen ise "Genellikle okul yöneticileri bu duruma sicak bakmıyor. (K61)" şeklinde görüş bildirmiştir. Yine öğretmenlerden 2'sinin güvenlikten kaynaklanan sorunlar yaşadığı görülmüş̧ür. Bu kapsamda bir öğretmen "Okul bahçesinin üç ayrı yerden giriş ve çıkışı var, risk almak istemiyorum. (E81)" derken bir diğer öğretmen ise "Güvenlik problemleri. (E31)" şeklinde görüş bildirmiştir.

\section{TARTIŞMA VE SONUÇ}

Araştırmaya katılan fen bilimleri öğretmenlerinin okul dışı eğitim alanlarından biri olan okul bahçelerini kullanmaya pozitif baktığı fakat öğretmenlerin genel olarak okul bahçelerini çok sıklıkla kullanmadıkları, kullananların ise düzensiz aralıklarla kullandıkları tespit edilmiştir. Dolayısıyla bu çalışma Carrier (2009)'in bulguları ile örtüşmektedir. Ayrıca Skelly ve Bradley (2000) yaptıkları çalışmada öğretmenlerin okul bahçesini derslerinde düzensiz aralıklarla kullandıklarını ifade ettikleri görülmektedir. Okul bahçesinin kullanılmama nedeni olarak en çok belirtilen problem ise ders esnasında bahçede oluşan öğrenci yoğunluğu ve bahçenin fiziki açıdan yetersiz oluşudur. Bu sonuçlar literatürdeki çalışmalarla örtüşmektedir. Nitekim Malkoç ve Kaya (2015) yaptıkları çalışmalarda okul bahçesi gibi sınıf dışı ortamları kullanmama sebepleri arasında bahçenin fiziki olarak yetersiz olduğu ve öğrenci sayısının fazla olduğu sonucuna ulaşmışlardır. Yine Şişman ve Gültürk (2011) ise okul bahçelerinin sahip oldukları yapısal-bitkisel materyaller ve alan açısından yetersiz olduğunu ifade etmişlerdir. Bu kapsamda 19 okul ile yapılan başka bir araştırma sonucunda ise okul bahçelerinde öğrenci başına düşen alanın yetersiz olduğu ve incelenen okul bahçelerinin işlevlerini yerine getirme konusunda da yetersiz olduğu ifade edilmiştir (Vural \& Yılmaz, 2018). Okul bahçelerinin kullanılmama nedenlerinden bir diğerinin ise öğretmenin sınıf yönetimini yeterli düzeyde sağlayamaması ve zaman yetersizliği olarak karşımıza çıkmaktadır. Bu kapsamda Oral ve Şentürk (2008) yaptığı çalışmada Türkiye'de sınıf yönetimi ile ilgili araştırma sonuçlarının, öğretmenlerin sınıf yönetiminin birçok boyutunda yetersiz olduğunu ifade etmiştir. Yine Dillon, Rickinson, Teamey, Morris, Choi, Sanders ve Benefield (2006) de öğretmenlerin derslerinde zaman problemi yaşadıkları sonucuna ulaşmışlardır. Ayrıca yapılan başka bir çalışmada okul dışı etkinliklerin müfredatta belirtilen ders süresi dahilinde yapılmasının zaman 
sıkıntısına sebep olduğu ifadesi belirlenmiştir (Erten \& Taşçı, 2016). Bu kapsamda yapılan çalışma sonuçları literatürle paralellik arz etmektedir. Ayrıca öğretmenler bahçe koşulları nedeniyle ders esnasında öğrencilerde meydana gelen dikkat dağınıklığı, bahçede kullanmak için gerekli olan araç-gereçlerin yetersiz oluşu, mevsimsel etmenlerin bahçede ders işlemek için elverişsiz oluşu, okul idaresinin okul bahçesi kullanımı konusunda problem teşkil etmesi ve olası kazalarda okul yönetimiyle anlaşmazlıklar oluşması, bahçe ve öğrenci güvenliğine dair yetersizlikler gibi problemler yaşadıklarını ifade etmiştir.

Araştırmaya katılan ve okul bahçesini kullanan öğretmenler de okul bahçesi kullanımı esnasında benzer birtakım problemlerle karşılaştıklarını ifade etmiştir. Bunlardan en sık karşılaşılan sorunların başında öğretmenlerin sınıf yönetimi konusunda zorluk çekmesi gelmektedir. Literatürde benzer sonuçlara ulaşmak mümkündür. $\mathrm{Bu}$ kapsamda yapılan bir çalışmada öğretmenlerin okul dışı öğrenme alanlarının kullanımında disiplin sorunlarıyla karşılaştıklarını dile getirdiği tespit edilmiştir (Çiçek \& Saraç, 2017). Yapılan bir diğer çalışmada ise sınıf yönetiminde karşılaşılan başlıca problemin öğrencilerin derse olan ilgisizliği olduğu ifade edilmiştir (Dirlikli, Sakallı \& Akgün, 2015). Okul bahçesini kullanan öğretmenlerin karşılaştıkları diğer sorunlar ise sırasıyla bahçenin fiziki açıdan yetersiz oluşu, öğrencilerde ders esnasında meydana gelen dikkat dağınıklığı, mevsimsel etmenlerin bahçede ders işlemek için elverişsiz oluşu, bahçe ve öğrenci güvenliğine dair yetersizlikler, öğrencilerin açık alanda duyma ve not alma konusunda zorluk çekmeleri, bahçede kullanmak için gerekli olan araç-gereçlerin yetersiz oluşu, okul idaresinin fen derslerinde okul bahçesinin kullanımına sıcak bakmaması olarak sıralanabilir. Yapılan çalışmalarda okul dişı alanlarda eğitim yapmak için gerekli izinlerin alınmasında zorluklar yaşandığı belirlenmiştir (Erten \& Taşçı, 2016).

Araştırma verileri öğrenme alanları açısından incelendiğinde öğretmenlerin okul dışı alanlardan biri olan okul bahçelerini 5. sınıflarda en fazla "Canlılar ve Yaşam", 6. sinıflarda en fazla "Fiziksel Olaylar", yine 7. sinıflarda en fazla "Fiziksel olaylar", 8. sinıflarda ise en fazla "Dünya ve Evren" öğrenme alanlarında kullandıkları tespit edilmiştir. Bu bağlamda Bulunuz, Bulunuz ve Peker (2014) yaptıkları araştırmada fen dersinde sınıf dışı aktivitelere katılan ve kitaba bağlı kalan öğrencilerin performanslarını değerlendirmiş ve temel fizik kavramlarını anlamada sınıf dışı aktivitelere katılan öğrencilerin çok daha başarılı olduğu sonucuna vardığını ifade etmiştir. Ayrıca Tepebağ ve Arnas'ın (2017) yaptıkları çalışmada okul bahçelerinin gelişimi destekleme, yaşayarak öğrenme ve materyal toplama amacıyla kullandığını ifade ettikleri görülmektedir.

Araştırma katılan öğretmenlerin diğer meslektaşlarına çeşitli önerilerde bulundukları belirlenmiştir. Bu kapsamda öğretmenlerin meslektaşlarına en sık bahçede etkinlik yapmadan önce etkinliğin mutlaka planlanması yönündeki önerisidir. Bozdoğan, Okur ve Kasap (2015) yaptıkları çalışmada okul dışı öğrenme ortamlarından birinde öğretim gerçekleştirmeden önce mutlaka gerekli planların yapılması gerektiği yönünde vurguda bulunmaktır. Yine planlama başlığı altındaki bir diğer tavsiye ise ders yapılan öğrencilerin dikkatlerini konuya çeken etkinlikler seçilmesi gerektiği yönündedir. Bir diğer tavsiye ise etkinliklerin bahçeye ve konuya uygun olmasına dikkat edilmesi gerektiği yönündedir. Ayrıca öğretmenlerin etkinlik yönergesinin bahçeye çıkmadan önce dağıtılması-açıklanması ve zaman sıkıntısı yaşamamak için zaman planlaması yapılması gerektiği yönünde tavsiyelerde bulunduğu görülmektedir. $\mathrm{Bu}$ kapsamda yapılan bir çalışmada iyi planlanan, broşürler ve yönergelerle, etkinlik esnasında kullanılacak olan çalışma kâğıtlarıyla desteklenen bir okul dışı eğitim faaliyetinin amaçlarına ulaştığına dair ifadeler belirtilmektedir (Bozdoğan, Okur \& Kasap, 2015). Ayrıca Bozdoğan (2008) yaptığı çalışmada informal eğitim ortamlarında bir etkinlik yapmadan önce etkinliğin planlanmasının eğitimin amacına ulaşmasında etkili rol oynadığını belirtmiştir. Yine öğretmenlerin meslektaşlarına okul yönetiminden destek alınarak okul bahçesini fen bilimleri 
dersi için uygun hale getirmek ve kalabalık sınıflarda yardımcı öğrenciler seçmek gerektiği önerilerinde bulunmuşlardır. Yapılan çalışmalar okul bahçesinin kullanımında okul idaresinden ve okul aile birliğinden destek alınmasının okul bahçesinin kullanımında çok daha iyi sonuçlar doğuracağ 1 belirtilmektedir (Özer, 2007).

Bununla birlikte öğretmenlerin olası kazalar için gerekli güvenlik tedbirlerinin alınması noktasında da meslektaşlarına önerilerde bulundukları belirlenmiştir. Bu kapsamda yapılan bir çalışmada öğretmenlerin okul dışı aktivitelerin öğrencilere pozitif yönde katkılar sağladığını düşündügü fakat güvenlik risklerinden dolayı endişe duydukları ifade edilmiştir (Bozdoğan, 2008). Yapılan çalışmanın sonuçları literatürle paralellik göstermektedir. Ayrıca yapılan bir diğer çalışmada ise okul bahçelerinin bazı etkenlerinin öğrenciler için güvenlik tehdidi oluşturduğu ifade edilmiştir (Karadağ, Mutlu \& Sayın, 2012). Öğretmenlerin bir diğer önerisi ise bazı konu ve üniteler için bahçede çizim ve şekiller kullanılması gerektiğidir. Bu bağlamda yapılan bir araştırmada öğretmenlerin okul bahçesine şekiller çizerek okul bahçesi kullanımını artırmayı amaçladığı ve pozitif yönde geri dönüt aldıkları ifade edilmiştir (Bucher, 2017).

Araştırmaya katılan öğretmenlere ait veriler incelendiğinde fen bilimleri öğretmenlerinin derslerinde okul bahçesi kullanmalarının öğrencilere birçok bakımdan katkı sağladığını ifade ettikleri görülmektedir. Bu ifadeler incelenmiş ve bilişsel, duyuşsal ve psiko-motor beceriler başlıkları altında ayrıştırılmıştır. Öğretmenler okul bahçelerinin yaparak ve yaşayarak öğrenme, oyun oynayarak öğrendiği bilgileri kalıcı hale getirme yönleriyle psiko-motor açıdan, kavramada kolaylık sağlama ve başka disiplinlerle ilişki kurmaya yardımcı olma yönleriyle bilişsel açıdan, dersi daha heyecanlı hale getirme ve eğlenerek öğrenmeyi sağlama yönleriyle duyuşsal açıdan öğrencilere kazandırdığı olumlu kazanımların olduğunu ifade etmiştir. Kubat (2018) da yaptığı çalışmada okul dışı öğrenme ortamlarının programda bulunan kazanımların gerçekleşmesine ve öğrenmenin kalıcı olmasına olanak sağladığına yönelik olumlu katkılarının olduğunu ifade etmiştir. Ayrıca literatür incelemesi yapıldığında sınıf dişı etkinliklerin öğrencilerin akademik başarılarını büyük ölçüde artırdığına ilişkin çalışmalar olduğu görülmektedir (Alp, Ertepınar \& Tekkaya, 2006; Bozdoğan, 2007; Bozdoğan \& Yalçın, 2006; Rennie \& McClafferty, 1995; Şahin \& Sağlamer-Yazgan,2013). Ürey, Göksu ve Ataman (2017) ise sınıf dışı etkinliklerin disiplinler arası alternatif bir öğrenme yöntemi olduğuna vurgu yapmaktadır. Ayrıca Bozdoğan ve Kavcı (2016) yaptıkları çalışmada sınıf dışında işlenen dersin konuyu görselleştirme, somutlaştırma, yarışma-oyun haline getirme ve öğrencilerin aktif olarak derse katılımını sağlaması bakımından öğrencilerin başarısı ve derse olan ilgilerini artırdı ğını ifade etmektedir.

Araştırmadan elde edilen sonuçlar şu şekildedir:

1. Araştırmaya katılan 113 fen bilimleri öğretmenin yaklaşık beşte üçünün (64 kişi) okul bahçesini derslerinde kullandığı belirlenmiştir. Bu öğretmenlerin yaklaşık yarısının (33 kişi) okul bahçesini düzensiz aralıklarla kullandığı ve yaklaşık üçte ikisinin de okul bahçesini ders anlatımı amacıyla kullandığı belirlenmiştir.

2. Ortaokul 5. 6. 7. ve 8. sınıf fen bilimleri derslerindeki öğrenme alanları genel olarak ele alındığında fen bilimleri öğretmenlerinin en sık "Fiziksel Olaylar" öğrenme alanı konularının öğretiminde okul bahçesini kullandığı görülmektedir. Yine bunu "Canlılar ve Yaşam” öğrenme alanı ve "Dünya ve Evren" öğrenme alanlarının takip ettiği tespit edilmiştir. "Madde ve Doğası" öğrenme alanı konularının öğretiminde öğretmenlerin okul bahçesini en az tercih ettiği tespit edilmiştir.

3. Araştırmaya katılan öğretmenlerin okul bahçesi kullanım sürecinde en sık sınıf yönetimine ilişkin sorunlar yaşadığı tespit edilmiştir. Bu sorunları sırasıyla bahçenin fiziki yetersizliği, 
öğrencilerdeki dikkat dağınıklığı ve mevsimsel etmenler, güvenlik eksikleri, açık alanda duyma ve not alma, araç-gereç yetersizliği gibi sorunlar takip etmektedir. En az karş1laşılan sorunun ise okul idaresinden kaynaklanan sorunlar olduğu tespit edilmiştir.

4. Derslerinde okul bahçesini kullanmayan öğretmenlerin okul bahçesini kullanmama sebeplerinin başında bahçedeki öğrenci yoğunluğunun olduğu belirlenmiştir. Yine bunu bahçenin fiziki yetersizliği, sınıf yönetiminin yeteri kadar sağlanamaması, bahçeye ihtiyaç duymama (sınıf ve laboratuvarları yeterli görme), bahçenin konu ve ünitelere uygun olmayışı, zaman yetersizliği, öğrencilerde meydana gelen dikkat dağınıklıkları, araç-gereç yetersizlikleri, mevsimlerden kaynaklanan kötü hava şartları ve okul idaresi ile yaşanan anlaşmazlıklar gibi etmenler takip etmektedir. En az karşılaşılan etmenin ise güvenlik yetersizliğinden kaynaklandığ 1 belirlenmiştir.

5. Derslerinde okul bahçesini kullanan 64 fen bilimleri öğretmeninin yarısının meslektaşlarına çeşitli öneride bulunduğu diğer yarısının ise herhangi bir öneride bulunmadığı tespit edilmiştir. Bu kapsamda öğretmenlerin en sık "Planlama" ile ilgili önerilerinin olduğu tespit edilmiştir. Bu kapsamda en sık karşılaşılan öneri bahçede etkinlik yapmadan önce etkinliğin kesinlikle planlanması gerektiği yönündedir. Yine bunu sırasıyla grubun dikkatini konuya toplayacak etkinlikler seçilmesi, etkinliklerin bahçeye ve konuya uygun olduğundan emin olunması, etkinlik yönergesini bahçeye çıkmadan önce öğrencilere dağıtılması ve açıklanması ayrıca zaman sıkıntısı yaşamamak için zaman planlaması yapılması gerektiği ifadeleri takip etmektedir. Öğretmenlerin bir diğer önerisi ise "Destek" başlı̆̆ı altında toplanmıştır. Bu başlık altında en sık karşılaşılan öneri ise okul yönetiminden destek alarak, okul bahçesini fen bilimleri dersi için verimli hale getirmek yönündedir. Bunu kalabalık sınıflarda yardımcı öğrencilerin görevlendirilmesi gerektiği önerisi takip etmektedir. Yine öğretmenlerin bir diğer önerisi "Güvenlik" başlığı altında toplanmıştır. Bu başlık altında ise öğretmenler olası kazalar için gerekli güvenlik önlemlerinin alınması gerektiği yönünde çeşitli önerilerde bulunmaktadır. Son olarak "Uygulama" başlığı altında toplanan önerilerde ise öğretmenlerin bazı konu ve üniteler için bahçede çizim ve şekiller kullanılabileceği yönünde öneride bulundukları belirlenmiştir.

6. Derslerinde okul bahçesi kullanan öğretmenlerin, bu sayede öğrencilerin en sik psikomotor (yapma, hayata geçirme, zihin ve kas becerilerini birlikte kullanma) becerilerinin gelişebileceğini ifade ettikleri tespit edilmiştir. Bunu sırasıyla bilişsel (açıklama, inceleme, hatırlama, gösterme, deneme, ilişkilendirme) beceriler ve duyuşsal (değer verme, saygılı olma, motivasyon, iş birliği, heyecanlanma) becerilerin takip ettiğini görülmüsstür.

Yapılan çalışmanın sonucunda araştırmaya katılan öğretmenlerin görüş ve önerileri de dikkate alınarak aşağıdaki önerilerde bulunulmuştur;

Öğretmenlerin yaklaşık yarısının okul bahçesini kullandığı göz önünde bulundurulduğunda öğretmenlerin bahçe kullanım oranını artırmak için fen müfredatına okul bahçesinin daha çok kullanılabileceği etkinlikler eklenebilir. Bunun yanında, araştırmaya katılan öğretmenlerin okul bahçesini en az "Madde ve Doğası" öğrenme alanı konu ve kavramlarında kullandıkları dikkate alındığında bu öğrenme alanı için ders kitaplarına okul bahçesi etkinlikleri eklenebilir.

Öğretmenlerin okul bahçesi kullanım sürecinde en sık sınıf yönetimine ilişkin sorunlar yaşadığı dikkate alındığında, MEB tarafından tüm okullarda öğretmenlere çeşitli seminerler verilerek ve broşürlerle desteklenerek, öğretmenlerin okul bahçesinde sınıf yönetimini nasıl sağlayabileceğine dair bilgi edinmeleri sağlanabilir. Yine bu konuda öğretmen adaylarına sadece teorik değil uygulamalı seçmeli dersler verilmesi ve öğretmen adaylarının iş yaşamlarına çok daha donanımlı başlayabilmelerine olanak tanınması da önerilebilir. Ayrıca okul bahçelerinde fen bilimleri dersi için bahçenin yeşil bir bölümünün ayrılması ve öğrencilerin 
bahçe içinde dahi daha izole bir ortamda ders işlemesine olanak sağlamasının sınıf yönetimi sorunlarını giderme açısından öğretmene büyük kolaylık sağlayacağı düşünülmektedir.

Yurt dışındaki örneklerde de görüleceği gibi özellikle "Canlılar ve Yaşam” öğrenme alanını destekleyici küçük seralar kurmanın ve öğrencilerin bu alanda bitki büyütmelerinin hem ögrencilerin sorumluluk alma duygularını geliştireceği hem de sınıf dışı bir ortamda daha fazla eğlenerek ve uygulayarak öğrenmelerine olanak sağlayacağı düşünülmektedir.

Bu alanların etkin kullanımına yönelik farkı konularda, farklı derslerde ve sınıf düzeylerinde de çalışmalar yapılabilir. Yine yapılacak çalışmalarda kırsal ve kentsel bölgeler karşılaştırılabilir. Aynı zamanda özel okullar ve devlet okullarının okul bahçeleri ve buna bağlı olarak öğrenci başarı yüzdeleri karşılaştırılabilir. Ayrıca yurt dışındaki okul bahçeleri ile ülkemizdeki okul bahçeleri karşılaştırılabilir ve bu bağlamda eksikler ve hatalar belirlenip gerekli reformların yapılmasına ön hazırlık sunulabilir.

\section{KAYNAKÇA}

Aktekin, S. (2008). Müze uzmanlarının okulların eğitim amaçlı müze ziyaretlerine ilişkin görüşleri. Ahi Evran Üniversitesi Kırşehir Ĕ̈itim Fakültesi Dergisi, 9(2), 103-111.

Alp, E., Ertepinar, H., Tekkaya C. \& Yilmaz, A. (2006). A statistical analysis of children's environmental knowledge and attitudes in Turkey. International Research in Geographical and Environmental Education, 15(3), 210-223.

Balc1, A. (2005). Sosyal bilimlerde araştırma. Ankara: Pegem A Yayıncılık.

Balkan Kıyıc1, F. \& Atabek Yiğit, E. (2010). Science education beyond the classroom: A field trip to wind power plant. International Online Journal of Science Education, 28(12), 1373-1388.

Başar, M. A. (2020). İlkokul ve Ortaokulların Okul Yeri Durumları ve Okul Bahçesi Olanakları. Journal of Original Studies, 1(2), 61-84.

Baştürk, S. \& Taştepe, M. (2013). Bilimsel araştırma yöntemleri, Ankara: Vize Yayıncılık.

Berberoğlu, O. E. \& Uygun S. (2013). sınıf dişı eğitimin dünyadaki ve Türkiye'deki gelişiminin incelenmesi. Mersin Üniversitesi Eğitim Fakültesi Dergisi, 9(2), 32-42.

Blair, D. (2009). The child in the garden: An evaluative review of the benefits of school gardening. The Journal of Environmental Education, 40(2), 15-38.

Bozdoğan, A. E. (2007). Bilim ve teknoloji müzelerinin fen öğretimindeki yeri ve önemi. Yayımlanmamış Doktora Tezi. Gazi Üniversitesi Eğitim Bilimleri Enstitüsü, Ankara.

Bozdoğan, A. E. (2008). Fen bilgisi öğretmen adaylarının bilim merkezlerini fen öğretimi açısından değerlendirilmesi: Feza Gürsoy Bilim Merkezi örneği. Uludă̆ Eğitim Fakültesi Dergisi, 21(1), $19-$ 41.

Bozdoğan, A. E. (2015). Okul dışı çevrelere eğitim amaçlı gezi düzenleyebilme öz- yeterlik inancı ölçeğinin geliştirilmesi. Kuramsal Eğitim bilim Dergisi, 9(1), 111-129.

Bozdoğan, A. E. \& Yalçın, N. (2006). Bilim merkezlerinin ilköğretim öğrencilerinin fene karşı ilgi düzeylerinin değişmesine ve akademik başarısına etkisi: Enerji parkı. Ege Eğitim Dergisi, 2(7), 95114.

Bozdoğan, A.E., Okur, A. \& Kasap, G. (2015). Planlı bir alan gezisi için örnek uygulama: Bir fabrika gezisi. Karadeniz Sosyal Bilimler Dergisi, 7(2), 79-90.

Bucher, K. (2017). Opening garden gates: Teachers making meaning of school gardens in Havana and Philadelphia. Teaching and Teacher Education, 63, 12-21.

Bulunuz, N., Bulunuz, M. \& Peker, H., (2014). Effects of formative assessment probes integrated in extracurricular hands-on science: Middle school students' understanding. Journal of Baltic Science Education, 13(2), 243-258.

Carrier, S. J. (2009). The effects of outdoor science lessons with elementary school students on preservice teachers' self-efficacy. Journal of Elementary Science Education, 21(2),35-48.

Cohen, L., Manion, L. \& Morrison, K. (2007). Research methods in education (6th ed.). New York, NY: Routledge. 
Creswell, J. W. (2003). Research design: Qualitative, quantitative, and mixed methods approaches (2nd ed.). Thousand Oaks, CA: Sage.

Çiçek, Ö. \& Saraç, E. (2017). Fen bilimleri öğretmenlerinin okul dışı öğrenme ortamlarındaki yaşantıları ile ilgili görüşleri. Ahi Evran Üniversitesi Kırşehir Eğitim Fakültesi Dergisi, 18(3), 504-522.

Dillon J., Rickinson, M., Teamey, K., Morris, M., Choi, M. Y., Sanders, D. \& Benefield, P. (2006). The value of outdoor learning: evidence from research in the UK and elsewhere. School Science Review, 87(320), 107-111.

Dirlikli, M., Sakallı, A. F. \& Akgün, L. (2015). Matematik öğretmenlerinin sinıf yönetiminde karşılaştıkları sorunlar. Uluslararası Eğitim Bilimleri Dergisi, 5,36-57.

Eliason, C. \& Jenkins, L. (2003). A practical guide to early childhood curriculum (7th ed.). Upper Saddle River, NJ: Prentice Hall.

Ertaş, H., Şen, A. İ. \& Parmaksızoğlu, A. (2011). Okul dışı bilimsel etkinliklerin 9. sınıf öğrencilerinin enerji konusunu günlük hayatla ilişkilendirme düzeyine etkisi. Necatibey Eğitim Fakültesi Elektronik Fen ve Matematik Eğitimi Dergisi, 5(2), 178-198.

Erten, Z. \& Taşçı, G. (2016). Fen Bilgisi Dersine Yönelik Okul Dışı Öğrenme Ortamları Etkinliklerinin Geliştirilmesi ve Öğrencilerin Bilimsel Süreç Becerilerine Etkisinin Değerlendirilmesi. Erzincan Üniversitesi Ë̆itim Fakültesi Dergisi, 18(2), 638-657.

Eshach, H. (2007). Bridging in-school and out of school learning: Formal, non-formal, and informal education. Journal of Science Education and Technology, 16, 171-190.

Falk, J. H. \& L. M. Adelman. (2003). Investigating the impact of prior knowledge and interest on aquarium visitor learning. Journal of Research in Science Teaching 40(2), 163-176.

Fraenkel, J. R. \& Wallen, N. (2000). How to design and evaluate research in education (4th ed.). NY: McGraw-Hill.

Geušić, J. (2020). Plant species selection for school garden and gardening activities plan in PS Rude. Master dissertation, University of Zagreb. Faculty of Agriculture. Department of Ornamental Plants, Landscape Architecture and Garden Art.

Graham, H., Beall, D. L., Lussier, M., McLaughlin, P. \& Zidenberg-Cherr, S. (2005). Use of school gardens in academic instruction. Journal of Nutrition Education and behavior, 37(3), 147-151.

Güler, T. (2009). Ekoloji Temelli Bir Çevre Eğitiminin Öğretmenlerin Çevre Eğitimine Karş1 Görüsslerine Etkileri. Eğitim ve Bilim, 34, 146-151.

Iş11, B., (1991), Ergonomi. İzmit: Yıldı Üniversitesi Yayınları, No: 228.

Karadă̆, A. A., Mutlu, S. \& Sayın, Ş. (2012). Okul bahçelerinin oyun alanı olarak değeri: Düzce kenti örneği. Düzce Üniversitesi Ormancllık Dergisi, 8(2), 45-56.

Karademir, E. (2013). Öğretmen ve ögretmen adaylarının fen ve teknolojisi dersi kapsamında' okul dışı ögrenme etkinliklerini' gerçekleştirme amaçlarının planmış davranış teorisi yoluyla belirlenmesi. Yayımlanmamış Doktora Tezi, Hacettepe Üniversitesi Sosyal Bilimler Enstitüsü, Ankara.

Kılıç, E. (2001). Öğrenme Psikolojisi. İstanbul: Alfa Basım Yayım Dă̆ıtım.

Kubat, U. (2018). Okul Dışı Öğrenme Hakkında Fen Bilgisi Öğretmen Adaylarının Görüşleri. Mehmet Akif Ersoy Üniversitesi Ĕ̈itim Fakültesi Dergisi, 48, 111-135.

Malkoç, S. \& Kaya, E. (2015). Sosyal bilgiler öğretiminde sınıf dışı okul ortamlarının kullanılma durumları. Illkögretim Online [Elementary Education Online], 14(3). 1079-1095.

Milli Eğitim Bakanlığı [MEB]. (2005). Talim Terbiye Kurulu Başkanlı̆̆l, İlköğretim fen ve teknoloji dersi (6,7 ve 8. Siniflar) ögretim programı. Ankara: Devlet Kitapları Basım Evi.

Milli Eğitim Bakanlığı [MEB]. (2018). Talim ve Terbiye Kurulu Başkanlı̆̆l, ilköğretim fen bilimleri dersi (3, 4, 5, 6, 7 ve 8. Sinıflar) ögretim programı. Ankara: MEB Yayınları.

Morgan, P. J., Warren, J. M., Lubans, D. R., Saunders, K. L., Quick, G. I. \& Collins, C. E. (2010). The impact of nutrition education with and without a school garden on knowledge, vegetable intake and preferences and quality of school life among primary-school students. Public Health Nutrition, 13(11), 1931-1940.

Onwuegbuzie, A. J. \& Leech, N. L. (2004). Enhancing the interpretation of "Significant" findings: The role of mixed methods research. The Qualitative Report, 9(4), 770-792.

Orion, N. \& Hofstein, A. (1994). Factors that influence learning during a scientific field trip in a natural environment. Journal of Research in Science Teaching 31(10), 1097-1119. 
Özer, E. J. (2007). The effects of school gardens on students and schools: Conceptualization and considerations for maximizing healthy development. Health Education \& Behavior, 34(6), 846863.

Papadopoulou, A., Kazana, A. \& Armakolas, S. (2020). Education for sustainability development via school garden. European Journal of Education Studies, 7(9), 194-206.

Rennie, L.J. \& McClafferty, T.P. (1995). Using visits to interactive science and technology centers, museums, aquaria, and zoos to promote learning in science. Journal of Science Teacher Education, $6,175-185$.

Riggs, C. M. (2020). Science in the Garden: Place-Based Learning as Education Enrichment. Doctoral dissertation, Southern Illinois University at Edwardsville, ABD.

Robinson, C. W. \& Zajicek, J. M. (2005). Growing minds: The effects of a one-year school garden program on six constructs of life skills of elementary school children. Hort Technology, 15(3), 453457.

Rye, J. A., Selmer, S. J., Pennington, S., Vanhorn, L., Fox, S. \& Kane, S. (2012). Elementary school garden programs enhance science education for all learners. Teaching Exceptional Children, 44(6), 58-65.

Saraç, H. (2017). Türkiye'de Okul Dışı Öğrenme Ortamlarına İlişkin Yapılan Araştırmalar: İçerik Analizi Çalışması. Eğitim Kuram ve Uygulama Araştırmaları Dergisi, 3(2), 60-81.

Skelly, S. M. \& Bradley, J. C. (2000). The importance of school gardens as perceived by Florida elementary school teachers. HortTechnology, 10(1), 229-231.

Smith, W.S., McLaughlin, E. \& Tunnicliffe, S.D. (1998). Effect on primary level students of in-service teacher education in an informal science setting. Journal of Science Teacher Education, 9(2), 123142.

Stephen, P. \& Crawley, T., (1994), Becoming An Effective Teacher, Cheltenham: Stanley Thornes Ltd.

Sturm, H. \& Bogner, F. X. (2010). Learning at Workstations in Two Different Environments: A museum and a classroom. Studies in Educational Evaluation, 36, 14-19.

Şahin, F. \& Sağlamer- Yazgan, B. (2013). Araştırmaya dayalı sınıf dışı laboratuar etkinliklerinin öğrencilerin akademik başarısına etkisi. Sakarya University Journal of Education, 3(3), 107- 122.

Şentürk, H. \& Oral, B. (2008). Türkiye'de sınıf yönetimi ile ilgili yapılan bazı araştırmaların değerlendirilmesi. Elektronik Sosyal Bilimler Dergisi, 7(26), 1-13.

Şentürk, E. \& Özdemir, Ö. F. (2014). The effect of science centres on students' attitudes towards science, International Journal of Science Education, 4(1), 1-24.

Şişman, E. \& Gültürk, P. (2011). İlköğretim okul bahçelerinin peyzaj planlama ve tasarım ilkeleri açısından incelenmesi: Tekirdağ örneği. Tekirdă̆ Ziraat Fakültesi Dergisi, 8(3), 53-60.

Tashakkori, A. \& Teddlie, C. (Eds). (2003). Handbook of mixed methods in social and behavioral research. Thousand Oaks, CA: Sage.

Tatar, N. \& Bağrıanık, K. E. (2012). Fen ve teknoloji dersi öğretmenlerinin okul dışı eğitime yönelik görüşleri. İlkögrretim Online, 11(4), 883-896.

Tepebağ, D. \& Arnas, Y. A. (2017). Okul öncesi öğretmenlerinin okul bahçesini eğitsel amaçlı kullanımına yönelik görüşlerinin incelenmesi. Uluslararası Erken Çocukluk Eğitimi Çalışmaları Dergisi, 2(2), 50-67.

Thorp, L. \& Townsend, C. (2001). Agricultural education in an elementary school: An ethnographic study of a school garden. In Proceedings of the 28th Annual National Agricultural Education Research Conference in New Orleans, LA (pp. 347-360).

Tortop, H. S. \& Özek, N. (2013). Proje tabanlı öğrenmede anlamlı alan gezisi; güneş enerjisi ve kullanım alanları konusu. Hacettepe Üniversitesi Eğitim Fakültesi Dergisi, 44, 300-307.

Ürey, M. \& Çepni, S. (2014). Fen temelli ve disiplinlerarası okul bahçesi programının öğrencilerin fen ve teknoloji dersine yönelik tutumları üzerine etkisinin farklı değişkenler açısından değerlendirilmesi. Ondokuz Mayıs Üniversitesi Eğitim Fakültesi Dergisi, 33(2), 537-548.

Ürey, M., Göksu, V. \& Karaçöp, A. (2016). Serbest etkinlik çalışmaları dersi kapsamında geliştirilen okul bahçesi programına yönelik öğretmen görüşleri. Elementary Education Online, 16(1), 1-14.

Vural, H. \& Yılmaz, S. (2018). Erzurum kenti okul bahçelerinin fiziki yeterlilikleri. Türk Tarım ve Doğa Bilimleri Dergisi, 5(2), 109-120. 
Wiegand, F., Kubisch, A. \& Heyne, T. (2013). Out- of- school learning in the botanical garden: Guided or self - determined learning at work stations? Studies in Educational Evaluation, 39, 161-168.

Yavuz, M. (2012). Fen eğitiminde hayvanat bahçelerinin kullanımının akademik başarı ve kayglya etkisi ve öğretmen-ögrenci görüşleri. Yayımlanmamış Yüksek lisans tezi, Sakarya Üniversitesi, Eğitim Bilimler Enstitüsü, Sakarya.

Yıldırım, A. \& Şimşek, H. (2005). Sosyal bilimlerde nitel araştırma yöntemleri. Ankara: Seçkin Yayıncilik.

\section{Kaynak gösterimi için (for cited in):}

Gülen, G. \& Bozdoğan, A. E. (2021). Fen bilimleri öğretmenlerinin derslerinde okul bahçelerini kullanma durumlarının incelenmesi. Turkish Journal of Primary Education (TUJPED), 6 (1), 89-108. doi: 10.52797/tujped.925015

\section{EXTENDED ABSTRACT}

\section{Introduction}

The science class environment's having limited sources to bring in the new knowledge which is acquired with the fast developments in science and technology to the society in an easy, understandable, and enjoyable way has caused the need for alternative environments. These places which are described as informal education environments include, science centers, zoos, botanic gardens, museums, libraries, aquariums, open air laboratories, nature centers, school gardens, and lots of social areas. One of the out of school environment is school gardens. School gardens have a significant environmental, educational, pedagogical, and didactic methodical function in the practice of primary schools. In this context the purpose of this study is the evaluation of use of school gardens by science teachers during their lectures in regards to different variables.

\section{Method}

This study is conducted with a total amount of 113 middle-school science teachers (53 male and 60 female) working in elementary schools in the city of Tokat, Turkey. In order to evaluate the status of use of school gardens by the teachers, a questionnaire consisting of two parts (the questionnaire for the status of use of school gardens) developed by the researcher is applied to the teachers. While the first part of the questionnaire contains demographic information regarding teachers' gender, seniority, graduation status, and the grade level of the teachers, the second part of the questionnaire contains open-ended questions regarding the use of school gardens. In this study, a mixed method combining both quantitative and qualitative data is used in order to examine the research topic in more detail. The research data in this study was collected by the researcher from the science teachers in person. Descriptive statistical methods of frequency and percentage were used for statistical solutions of the data for the sub-problems of the study, while the SPSS 26.0 package program and Multiple Response analysis were used for the questions with multiple answers. Open-ended questions are analyzed according to content analysis.

\section{Findings}

The results of the research show that almost half of the teachers use the school gardens in their lectures, and the majority of the teachers who do use the school garden at irregular intervals 
and as a replacement of lectures for the purpose of lecturing. In addition, in terms of learning categories for middle-school $5^{\text {th }}, 6^{\text {th }}, 7^{\text {th }}$, and $8^{\text {th }}$ grades, it is seen that teachers mostly use the school gardens in the "Physical Events" learning category. Moreover, it has been determined that teachers mostly experience classroom management problems followed by the physical inadequacy of the school garden and the distraction of students and seasonal problems while using the school garden in their lectures. The main reason for teachers who do not use the school garden in their lessons is the high density of students in the garden. In addition, it was determined that the physical insufficiency of the garden and the reasons related to classroom management were followed. However, teachers made various suggestions to their colleagues in order to use the school garden more effectively and efficiently.

\section{Conclusion and Discussion}

It was determined that the first of these suggestions is that the school garden activity should be planned beforehand. Additionally, the teachers stated that the use of school gardens supports the development of students' psychomotor, cognitive and affective skills. 